\title{
In Vitro Antioxidant and Antimicrobial Properties of Flower, Leaf, and Stem Extracts of Korean Mint
}

\author{
Chang Ha Park ${ }^{1,+}$, Hyeon Ji Yeo ${ }^{1,+}$, Thanislas Bastin Baskar ${ }^{1}$, Ye Eun Park ${ }^{1}$, Jong Seok Park ${ }^{2}$, \\ Sook Young Lee ${ }^{3, *}$ and Sang Un Park ${ }^{1, *}$ \\ 1 Department of Crop Science, Chungnam National University, 99 Daehak-Ro, Yuseong-gu, Daejeon 34134, \\ Korea; parkch804@gmail.com (C.H.P.); gusw17627@gmail.com (H.J.Y.); bastinbt20@yahoo.com (T.B.B.); \\ yeney1996@cnu.ac.kr (Y.E.P.) \\ 2 Department of Horticultural Science, Chungnam National University, 99 Daehak-ro, Yuseong-gu, \\ Daejeon 34134, Korea; jongseok@cnu.ac.kr \\ 3 Marine Bio Research Center, Chosun University, 61-220 Myeongsasimni, Sinji-myeon, Wando-gun, \\ Jeollanamdo 59146, Korea \\ * $\quad$ Correspondence: seedbank@chosun.ac.kr (S.Y.L.); supark@cnu.ac.kr (S.U.P.); Tel.: +82-10-8610-6739 (S.Y.L.); \\ +82-42-821-5730 (S.U.P.); Fax: +82-61-555-1260 (S.Y.L.); +82-42-822-2631 (S.U.P.) \\ + These authors contributed equally to this work.
}

Received: 8 March 2019; Accepted: 25 March 2019; Published: 26 March 2019

check for updates

\begin{abstract}
Traditionally, Agastache rugosa (Korean mint) has been widely used to treat various infectious diseases. The aims of this study were to: (i) determine the phenylpropanoid content of the plant using high-performance liquid chromatography; (ii) undertake total anthocyanin, flavonoid, and phenolic assays; (iii) and evaluate the antioxidant and antibacterial properties of the methanol extracts from the stem, leaves, and flowers of Korean mint. The total anthocyanin, flavonoid, and phenolic content assays showed that the flowers had higher phenolic levels than the stem and leaves. The reducing power, the 2,2-diphenyl-1-picrylhydrazyl superoxide radical scavenging abilities, and the hydrogen peroxide radical scavenging activities were also evaluated so that the antioxidant activities of the extracts from the different plant parts could be evaluated. The flower extracts revealed higher antioxidant properties than the other parts. The antibacterial properties of the methanol extracts from A. rugosa were analyzed by the disc diffusion method, and the flower extracts had higher antibacterial activities against the six bacterial strains used in the study than the other parts. This study provides information on the synergistic antioxidant and antibacterial properties of phenolics derived from the different parts of Korean mint.
\end{abstract}

Keywords: Korean mint; antioxidant activity; antibacterial activity; phenolics

\section{Introduction}

Agastache rugosa, which is also called Korean mint, belongs to the Lamiaceae family, and is a traditional medicinal and ornamental plant. It is mainly distributed in East Asia, and has been commercially cultivated and used as a spice or to prepare perfumes [1]. In particular, A. rugosa has been traditionally used as a herbal remedy for the treatment of anorexia, vomiting [2], cholera, and miasma [3-6]. Previous studies have reported that $A$. rugosa has various pharmacological and physiological properties, including anti-cancer [7], antibacterial [8], anti-fungal [9], and antiviral activities [10]. Bioassays of $A$. rugosa extracts have revealed a range of pharmacological and biological actions, including anti-fungal and anti-HIV properties, and it also inhibits Ha emophilus influenza adhesion to human cells [11]. Moreover, Oh et al. (2006) reported that ethyl acetate extracts of Korean mint have antibacterial, antioxidant, anti-mutagenic, and anti-cancer properties [12]. These activities are attributable to the various bioactive compounds that are present in A. rugosa. Previous 
studies have shown that $A$. rugosa contains many secondary metabolites, including phenylpropanoids, carotenoids, and terpenoids. Among these metabolites, the phenolic compounds from A. rugosa have been reported to have some biological activities; namely, the compounds are anti-complementary, anti-viral, anti-fungal, anti-inflammatory, and anti-atherogenic. Furthermore, Wilson et al. (1992) reported that Korean mint contains large concentrations of tilianin, which has been demonstrated to possess anti-atherogenic and anti-inflammatory properties [13].

Plant secondary metabolites are molecules that are not essential to plant survival, but have important plant development, growth, reproduction, and protection roles [14]. In particular, phenolics, which are widely distributed in higher plant species, possess biological properties associated with plant defense against biological and physical stresses [15,16]. Furthermore, the intake of edible plants containing many phenolic compounds is beneficial to human health due to their biological activities, as well as their anti-allergic, anti-cancer, anti-microbial, and antioxidant properties [17].

Reactive oxygen species (ROS) is a collective term that includes both oxygen and non-radicals that are generated during normal metabolic processes [18]. A serious imbalance between the production and scavenging of ROS induces oxidative stress, leading to various diseases, such as allergies, cancer, cardiac and vessel injuries, and infectious and neurodegenerative diseases [19]. Many scientific studies have reported that antioxidants play an important role in reducing the pathological conditions caused by the effects of free radicals, because the antioxidant agents are stable enough to scavenge or deactivate the oxidants [20]. Plants are considered to be a good source of natural antioxidants because they contain a variety of secondary metabolites that have antioxidant capacities [21,22]. Therefore, the dietary intake of plant-derived antioxidants should be increased to prevent oxidative stress and reduce the need to take additional medication [23].

This study determined the phenylpropanoid contents in A. rugosa by High Performance Liquid Chromatography (HPLC), and total phenolic, flavonoid, and anthocyanin assays were used to investigate the antioxidant and antibacterial activities of extracts from the stems, flowers, and leaves.

\section{Materials and Methods}

\subsection{Plant Material}

Two-month-old healthy and fresh leaves, flowers, and stems of Korean mint were harvested from the greenhouse at Chungnam National University, Daejeon, Korea. The cultivated plant materials were authenticated by a botanist in the department, and the plants were deposited under the voucher number SUP-16-0020. The harvested flowers, leaves, roots, and stems were washed with distilled water and then frozen in liquid nitrogen. Afterwards, these samples were freeze-dried in a freeze dryer (FD8512, Ilshin Lab Co. Ltd., Yangju, Korea) for $72 \mathrm{~h}$, operating at $-60^{\circ} \mathrm{C}$ and $1.33 \mathrm{~Pa}$. The dried organs were powdered using a pestle and mortar for further studies.

\subsection{Total Phenolic Content}

Fine powders $(100 \mathrm{mg})$ made from each plant part were extracted with $3 \mathrm{~mL}$ of methanol and sonicated for $1 \mathrm{~h}$. The extract was then centrifuged at 20,929 $\times g$ and filtered through a $0.45-\mu \mathrm{m}$ polytetrafluoroethylene (PTFE) hydrophilic syringe filter into a vial. The extracts were used for further experiments to determine the total phenolic, flavonoid, and anthocyanin contents. The Folin-Ciocalteu method was used to quantify the total phenolic content [24]. Exactly $100 \mu \mathrm{L}$ of crude extract was mixed with $3 \mathrm{~mL}$ of distilled water, and then $500 \mu \mathrm{L}$ of $2 \mathrm{~N}$ Folin and Ciocalteu's phenol reagent (Sigma-Aldrich Co., Yongin, Korea) was added. After incubation for $3 \mathrm{~min}$ at $28{ }^{\circ} \mathrm{C}, 2 \mathrm{~mL}$ of sodium carbonate $(20 \%, w / v)$ was added to the mixture, which was then incubated for $1 \mathrm{~h}$ in the dark. A UV-1800 spectrophotometer (Shimadzu Corp., Kyoto, Japan) was used to measure the absorbance of each sample at $760 \mathrm{~nm}$. A calibration curve equivalent (standard curve equation: $y=0.002 x-0.0226, r^{2}=0.9997$ ) was prepared using different gallic acid (Sigma-Aldrich Co., Yongin, Korea) solution concentrations, 
which ranged from 10 to $1000 \mu \mathrm{g} / \mathrm{mL}$. The final results are described as milligrams of gallic acid equivalent (GAE) per gram of dry weight (mg GAE/g dry weight).

\subsection{Total Flavonoid Content}

The total flavonoid content of the prepared methanol extract from each sample was determined using the colorimetric assay described by Kim et al. (2003) [25]. A 100- $\mu \mathrm{L}$ volume of each sample was mixed with $4 \mathrm{~mL}$ of distilled water in a 15-mL conical tube and $300 \mu \mathrm{L}$ of $\mathrm{NaNO}_{2}(5 \%, w / v)$. The solution was incubated for $5 \mathrm{~min}$; then, $300 \mu \mathrm{L}$ of $\mathrm{AlCl}_{3}(10 \%, w / v)$ was added. The mixture was incubated again for $6 \mathrm{~min}$; then, $2 \mathrm{~mL}$ of $\mathrm{NaOH}(1 \mathrm{M})$ was added. The final volume of the mixture was brought to $10 \mathrm{~mL}$ with deionized water. The mixture was incubated at $28^{\circ} \mathrm{C}$ for $15 \mathrm{~min}$, and the absorbance at $510 \mathrm{~nm}$ was measured. The final result was calculated using a calibration curve equivalent (standard curve equation: $y=0.001 x-0.0013, r^{2}=0.9994$ ) obtained using different concentrations of rutin (Sigma-Aldrich Co., Yongin, Korea), which ranged from 20 to $100 \mu \mathrm{g}$. The results are expressed as milligrams of rutin equivalent (RE) per gram of dry weight (mg RE/g dry weight).

\subsection{Total Anthocyanin Content}

The $\mathrm{pH}$ differential method, consisting of $\mathrm{KCl}$ buffer $(0.025 \mathrm{M}, \mathrm{pH} 1.0)$ and $\mathrm{CH}_{3} \mathrm{COONa}$ buffer $(0.4 \mathrm{M}, \mathrm{pH} 4.5)$, was used to determine the total anthocyanin content of the prepared methanol extract from each sample [26]. A 1-mL aliquot of the extract was mixed with $4 \mathrm{~mL}$ of each of the buffers and incubated at $28{ }^{\circ} \mathrm{C}$ for $15 \mathrm{~min}$ so that the solution could equilibrate. The absorbance reading was performed at $510 \mathrm{~nm}$ and $700 \mathrm{~nm}$ using deionized water as a blank. The absorbance (A) of each sample was calculated from an equation reported in a previous study [26]. The final result was converted to milligrams of cyanidin-3-glucoside equivalents (CGE) per gram dry weight (mg CGE/g dry weight).

\subsection{Liquid Chromatography-Mass Spectrometry (LC-MS) Analysis for the Quantification of Phenylpropanoid Content}

Phenolic compounds were identified using a system composed of an Agilent 1200 liquid chromatograph (Agilent Technologies, Palo Alto, CA, USA) coupled to a 4000 Qtrap LC/MS/MS system (Applied Biosystems Instrument, Foster City, CA, USA) in the negative ion mode $\left([\mathrm{M}-\mathrm{H}]^{-}\right)$. LC-MS conditions for the A. rugosa leaf were set as follows: scan range, 100-1300 m/ $z$; scan time, $4.80 \mathrm{~s}$; curtain gas, $20.00 \mathrm{psi}\left(\mathrm{N}_{2}\right)$; heating gas temperature, $550{ }^{\circ} \mathrm{C}$; nebulizing gas, $50.00 \mathrm{psi}$; heating gas, $50.00 \mathrm{psi}$; ion spray voltage, $5500 \mathrm{~V}$; declustering potential, $100 \mathrm{~V}$; and entrance potential, $10 \mathrm{~V}$.

\subsection{Phenylpropanoid Extraction and HPLC Analysis}

Phenylpropanoids were extracted and analyzed using a previously reported HPLC method with slight modification [27]. A total of $3 \mathrm{~mL}$ of aqueous methanol $(80 \%, v / v)$ was poured into a conical tube containing $0.1 \mathrm{~g}$ of the freeze-dried sample powders from the different Korean mint parts. Then, it was extracted in a sonicator at $37^{\circ} \mathrm{C}$ for $1 \mathrm{~h}$, followed by centrifugation at $1308 \times g$ for $10.5 \mathrm{~min}$. The supernatant was collected in a fresh tube and the whole procedure was repeated another two times. The collected aliquots were dried using nitrogen gas under a fume hood and resuspended in $3 \mathrm{~mL}$ of $80 \%$ methanol. An NS-4000 HPLC system (Futecs Co., Daejeon, South Korea) with a UV-Vis detector, a NS-6000 autosampler (Futecs Co., Daejeon, South Korea), and an OptimaPak C18 column $(250 \times 4.6 \mathrm{~mm}, 5 \mu \mathrm{m}$, RStech Co., Daejeon, South Korea) was used to separate the phenylpropanoids. The HPLC conditions were as follows: UV wavelength, $280 \mathrm{~nm}$; flow rate, $1.0 \mathrm{~mL} / \mathrm{min}$; injection volume, $20 \mu \mathrm{L}$; and column temperature, $30^{\circ} \mathrm{C}$. The phenylpropanoids were separated using the gradient program previously reported by Park et al. (2017) [27]. Identification was based on the retention time and spiking experiments followed by a calculation using a corresponding calibration curve. 


\subsection{Reducing Power Assay}

The reducing powers of the methanol extracts from the different organs were measured according to a previous method [28]. First, $0.2 \mathrm{M}$ of phosphate buffer ( $\mathrm{pH}$ 6.6) was prepared. Each reaction mixture contained $2.5 \mathrm{~mL}$ of $1 \% \mathrm{~K}_{3} \mathrm{Fe}(\mathrm{CN})_{6}$ and the methanol extract solutions (volumes ranged from 50 to $250 \mu \mathrm{L}$ ), to which about 2.5-mL aliquots of the buffer had been added, were then incubated at $50{ }^{\circ} \mathrm{C}$ for $20 \mathrm{~min}$. The mixtures were centrifuged at $2325 \times \mathrm{g}$ for $15 \mathrm{~min}$ after $2.5 \mathrm{~mL}$ of $10 \%$ trichloroacetic acid had been added. Approximately $2.5 \mathrm{~mL}$ of the supernatant was transferred to a fresh 15 Falcon tube and mixed with $0.5 \mathrm{~mL}$ of $1 \% \mathrm{FeCl}_{3}$ and $2.5 \mathrm{~mL}$ of distilled water. Ascorbic acid was used as a positive control. Then, the absorbance was measured at $700 \mathrm{~nm}$, and the increase in absorbance at $700 \mathrm{~nm}$ indicated a rise in the reducing power of each sample. All of the sample extracts were analyzed in triplicate.

\subsection{2,2-Diphenyl-1-picrylhydrazyl (DPPH) Free Radical Scavenging Assay}

The activities of the methanol extracts from the different organs were determined according to a previous method [28]. A 0.05-mM 2,2-diphenyl-1-picrylhydrazyl (DPPH•) solution in ice-cold methanol was prepared and $200 \mu \mathrm{L}$ of the DPPH• solution was added to each reaction mixture, which contained $3.8 \mathrm{~mL}$ of methanol and the extract $(50-250 \mu \mathrm{L}$ ). Ascorbic acid (vitamin C) was used as a positive control in the assay. Then, the mixtures were incubated at $37^{\circ} \mathrm{C}$ for $30 \mathrm{~min}$ in the dark, and the absorbance was measured at $517 \mathrm{~nm}$. All of the sample extracts were analyzed in triplicate. The DPPH free radical scavenging activity was calculated from the equation reported in a previous study [28].

\subsection{Hydrogen Peroxide Radical Scavenging Activity}

The activities of the methanol extracts from the different organs were measured according to a previous method [24]. Briefly, a 40-mM solution of $\mathrm{H}_{2} \mathrm{O}_{2}$ in phosphate buffer ( $\mathrm{pH}$ 7.4) was prepared; then, $0.6 \mathrm{~mL}$ of $\mathrm{H}_{2} \mathrm{O}_{2}$ was added to each reaction mixture, which contained $1 \mathrm{~mL}$ of distilled water and an aliquot of methanol extract $(50-250 \mu \mathrm{L})$. Ascorbic acid (vitamin C) was used as a positive control. Then, the mixtures were incubated at $37^{\circ} \mathrm{C}$ for $10 \mathrm{~min}$, and the absorbance was measured at $560 \mathrm{~nm}$. All of the sample extracts were analyzed in triplicate. The hydrogen peroxide radical scavenging activity was calculated from an equation reported in a previous study [24].

\subsection{Superoxide Radical Scavenging Activity}

The activities of the methanol extracts from the different organs were measured using nitroblue tetrazolium (NBT), according to a previously reported method [29]. Briefly, $24 \mathrm{mM}$ of NBT and $1 \mathrm{mM}$ of hydroxylamine hydrochloride were prepared. A total of $100 \mu \mathrm{L}$ of NBT ( $24 \mathrm{mM}$ ) was added into the reaction mixtures, which contained $0.2 \mu \mathrm{L}$ of $0.1 \mathrm{mM}$ of ethylenediaminetetraacetic acid (EDTA) solution, $1 \mathrm{~mL}$ of distilled water, and the methanol extract $(50-250 \mu \mathrm{L})$. Then, approximately $0.1 \mathrm{~mL}$ of hydroxylamine hydrochloride $(1 \mathrm{mM})$ was added to initiate the reaction. After incubation at $25^{\circ} \mathrm{C}$ for $20 \mathrm{~min}$, the NBT reduction was measured at $560 \mathrm{~nm}$ using a reaction mixture without any extract as the control. All of the sample extracts were analyzed in triplicate. The superoxide radical scavenging activity was calculated from an equation reported in a previous study [29].

\subsection{Extraction Process for Screening Antibacterial Activity}

First, $10 \mathrm{~g}$ of fine powders made from each plant part was soaked in $50 \mathrm{~mL}$ of solvent that contained ethanol, hexane, or methanol; then, the mixture was sonicated in an ultrasound bath (JAC-4020, KODO, Technical Research Co., Ltd., Hwaseong, Korea) for 1 day. Subsequently, an extract was collected using filter paper, and then the solvent was evaporated under nitrogen gas at room temperature and stored at $4{ }^{\circ} \mathrm{C}$ until needed for the antibacterial analysis. 


\subsection{Bacterial Cultivation}

Subsequently, an extract was collected using filter paper, and then the solvent was evaporated and stored at $4{ }^{\circ} \mathrm{C}$ until needed for analysis. Six bacterial strains-Aeromonas salmonicida (KACC 15136), Cronobacter sakazakii (ATCC 29544), Escherichia coli (KF 918342), E. coli (ATCC 35150), Staphylococcus haemolyticus, and Aeromonas hydrophila (KCTC 12487) - were obtained from the College of Medicine at Chungnam National University, Dajeon, Korea. All of the bacteria, except for S. haemolyticus, were gram-negative. The bacterial strains were shaken at $100 \mathrm{rpm}$ and cultured at $37^{\circ} \mathrm{C}$ to optical density at $600 \mathrm{~nm}(\mathrm{OD} 600)=0.1$ in a Luria-Bertani (LB) medium supplemented with a 50-mL aliquot of LB broth. Cultures of the mid-log phase bacteria were used for the antibacterial activity studies.

\subsection{Screening Antibacterial Activity Using the Disc Diffusion Method}

Different bacterial cultures, at an OD of 0.1 , were swabbed on 30-mL LB agar plates, and five distilled discs were then placed on the agar plates [30]. Sample volumes $(30 \mu \mathrm{L})$ of the extracts from different parts of Korean mint were added to the disc and then incubated at $37^{\circ} \mathrm{C}$ overnight. An antibiotic, streptomycin $(250 \mu \mathrm{g} / \mathrm{mL})$, was used as the standard antibacterial agent.

\subsection{Statistical Analysis}

Analysis of variance (ANOVA) and Duncan's multiple range tests (DMRTs) at $p<0.05$ were performed for the data from this current study using SAS software (version 9.4, 2013; SAS Institute, Inc., Cary, NC, USA). All of the data are represented as the mean \pm standard deviation of triplicate tests.

\section{Results}

\subsection{Total Phenolic, Flavonoid, and Anthocyanin Contents}

The Folin-Ciocalteu assay revealed that the greatest accumulation of total phenolics occurred in flowers $(24.53 \pm 1.01 \mathrm{mg} \mathrm{GAE} / \mathrm{g}$ dry weight $(\mathrm{dw}))$, followed by leaves $(17.57 \pm 0.91 \mathrm{mg} \mathrm{GAE} / \mathrm{g}$ $\mathrm{dw})$ and stems $(7.65 \pm 1.21 \mathrm{mg}$ GAE$/ \mathrm{g} \mathrm{dw})$. Similarly, the flowers contained the most flavonoids (18.52 $\pm 1.23 \mathrm{mg} \mathrm{RE} / \mathrm{g} \mathrm{dw})$. This level was 1.09 times higher than that in leaves $(16.91 \pm 0.23 \mathrm{mg} \mathrm{RE} / \mathrm{g}$ $\mathrm{dw})$, and 2.27 times higher than that in the stems $(8.17 \pm 0.47 \mathrm{mg} \mathrm{RE} / \mathrm{g} \mathrm{dw})$. The total anthocyanin content varied in the different parts and ranged from 0.01 to $0.22 \mathrm{mg}$ CGE/g dw. The highest total anthocyanin level was detected in the flowers $(0.22 \pm 0.09 \mathrm{mg}$ CGE $/ \mathrm{g} \mathrm{dw})$, followed by the leaves $(0.10 \pm 0.02 \mathrm{mg} \mathrm{CGE} / \mathrm{g} \mathrm{dw})$. However, the stems contained negligible amounts of anthocyanins $(0.01 \pm 0.00 \mathrm{mg}$ CGE/g dw) (Table 1).

Table 1. Total phenolics, flavonoid, and anthocyanin of the stem, leaves, and flowers of $A$. rugosa.

\begin{tabular}{cccc}
\hline Organ & $\begin{array}{c}\text { Total Phenolics } \\
(\mathbf{m g} \text { GAE/g dw) }\end{array}$ & $\begin{array}{c}\text { Total Flavonoid } \\
(\mathbf{m g ~ R E} / \mathbf{g} \mathbf{d w})\end{array}$ & $\begin{array}{c}\text { Total Anthocynin } \\
\mathbf{( m g ~ C G E / g ~ d w ) ~}\end{array}$ \\
\hline Flower & $24.53 \pm 1.01^{\mathrm{a}}$ & $18.52 \pm 1.23^{\mathrm{a}}$ & $0.22 \pm 0.09^{\mathrm{a}}$ \\
Leaf & $17.57 \pm 0.91^{\mathrm{b}}$ & $16.91 \pm 0.23^{\mathrm{b}}$ & $0.10 \pm 0.02^{\mathrm{b}}$ \\
Stem & $7.65 \pm 1.21^{\mathrm{c}}$ & $8.17 \pm 0.47^{\mathrm{c}}$ & $0.01 \pm 0.00^{\mathrm{b}}$ \\
\hline
\end{tabular}

Mean values with a different letters ( $a, b$, and $c$, respectively) were significantly different $(p<0.05$, ANOVA, DMRT) in the columns. DMRT: Duncan's multiple range test, GAE/g dw: gallic acid equivalent per gram of dry weight; RE/g dw: rutin equivalent per gram of dry weight; CGE/g dw: cyanidin-3-glucoside equivalents per gram dry weight.

\subsection{Phenylpropanoid HPLC Analysis}

As shown in Table S1 and Figure S1, a total of five phenolic compounds-namely, catechin, chlorogenic acid, caffeic acid, trans-p-hydroxy cinnamic methyl ester, and ferulic acid-and three flavonoids-tilianin, rutin, and kaempferol—were identified in A. rugosa leaves by LC-MS analysis. Compounds 1 to 8 showed major ion peaks at $m / z 289.5[\mathrm{M}-\mathrm{H}]^{-}, 445.6[\mathrm{M}-\mathrm{H}]^{-}$, 
$193.6[\mathrm{M}-\mathrm{H}]^{-}, 353.3[\mathrm{M}-\mathrm{H}]^{-}, 179.4[\mathrm{M}-\mathrm{H}]^{-}, 609.5[\mathrm{M}-\mathrm{H}]^{-}, 177.7[\mathrm{M}-\mathrm{H}]^{-}$, and $285.6[\mathrm{M}-\mathrm{H}]^{-}$, respectively. Of these eight, six compounds (catechin, chlorogenic acid, caffeic acid, ferulic acid, rutin, and kaempferol) were quantified with HPLC. Table 2 shows the phenylpropanoid content of the flowers, leaves, and stem. The levels of these phenylpropanoids varied among the three parts. The total phenylpropanoid content ranged from 0.433 to $1.570 \mathrm{mg} / \mathrm{g} \mathrm{dw}$ ), and the highest level was recorded in leaves. Among the individual phenylpropanoids, the highest levels of catechin, caffeic acid, and ferulic acid were obtained from leaves, and these levels were 37.101-fold, 1.202-fold, and 1.528-fold higher, respectively, than the lowest levels obtained from stems. Ferulic acid and kaempferol were not detected in the stems, but they did contain the most chlorogenic acid.

Table 2. The accumulation of phenolic compounds in the stem, leaves, and flowers of $A$. rugosa.

\begin{tabular}{cccccccc}
\hline \multirow{2}{*}{ Organ } & \multicolumn{5}{c}{ Phenolic Compounds (mg/g dw) } \\
\cline { 2 - 7 } & Catechin & Chlorogenic Acid & Caffeic Acid & Ferulic Acid & Rutin & Kaempferol & Total \\
\hline Flower & $0.014 \pm 0.005^{\mathrm{b}}$ & $0.011 \pm 0.006^{\mathrm{b}}$ & $0.267 \pm 0.001^{\mathrm{b}}$ & $0.815 \pm 0.001^{\mathrm{b}}$ & $0.061 \pm 0.009^{\mathrm{ab}}$ & $0.137 \pm 0.007^{\mathrm{a}}$ & $1.305 \pm 0.024^{\mathrm{b}}$ \\
Leaf & $0.148 \pm 0.005^{\mathrm{a}}$ & $0.027 \pm 0.021^{\mathrm{b}}$ & $0.327 \pm 0.030^{\mathrm{a}}$ & $0.830 \pm 0.001^{\mathrm{a}}$ & $0.081 \pm 0.012^{\mathrm{a}}$ & $0.157 \pm 0.021^{\mathrm{a}}$ & $1.570 \pm 0.064^{\mathrm{a}}$ \\
Stem & $0.004 \pm 0.003^{\mathrm{c}}$ & $0.103 \pm 0.010^{\mathrm{a}}$ & $0.272 \pm 0.003^{\mathrm{b}}$ & ND & $0.053 \pm 0.013^{\mathrm{b}}$ & ND & $0.433 \pm 0.022^{\mathrm{c}}$ \\
\hline
\end{tabular}

Mean values with a different letters ( $a, b$, and $c$, respectively) were significantly different $(p<0.05$, ANOVA, DMRT) in the columns. ND: not detected.

\subsection{In Vitro Antibacterial Activity}

The in vitro antibacterial activity tests revealed a zone of inhibition around the edge of the disc for each extract (Figure 1). The inhibition zones generated by the methanol extracts from the various plant parts are shown in Table 3. The methanolic extracts showed the most promising activities against the six bacterial strains (these results are not shown). Therefore, the ethanolic and hexane extracts were excluded from the study, and the methanolic extracts were used in subsequent studies. The methanol extract from the flowers had greater antibacterial properties than the stem and leaf extracts. In particular, the flower extracts possessed the greatest antibacterial activity against E. coli (KF 918342), followed by A. hydrophila, S. haemolyticus, A. salmonicida, E. coli (ATCC 35150), and C. sakazakii, in that order. The stem extracts had the lowest antibacterial activities against all the bacterial strains tested.

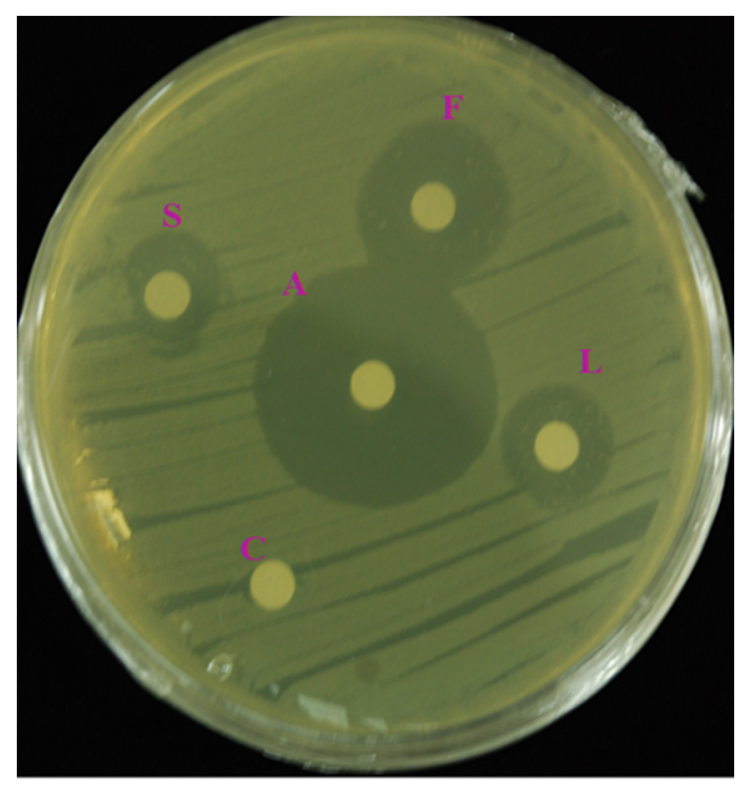

Figure 1. Representative image showing antibacterial activity against a bacterial pathogen. A-antibiotic (Streptomycin); C-control (methanol); F, L, and S are methanolic extracts; F-flower extract, L-leaf extract, and S-stem extract. 
Table 3. Antibacterial activity of the methanol extracts of stem, leaves, and flowers, of A. rugosa.

\begin{tabular}{ccccc}
\hline \multirow{2}{*}{ Bacterial Strain } & \multicolumn{4}{c}{ Zone of Inhibition (mm) } \\
\cline { 2 - 5 } & Flower & Leaf & Stem & Streptomycin \\
\hline E.coli (KF918342) & $18.3 \pm 0.5^{\mathrm{b}}$ & $14.0 \pm 1.0^{\mathrm{c}}$ & $11.0 \pm 1.0^{\mathrm{d}}$ & $27.6 \pm 0.6^{\mathrm{a}}$ \\
Staphylococcus hemolyticus & $16.6 \pm 0.5^{\mathrm{b}}$ & $12.0 \pm 1.0^{\mathrm{c}}$ & $8.0 \pm 1.0^{\mathrm{d}}$ & $26.3 \pm 0.6^{\mathrm{a}}$ \\
Aeromonas hydrophila & $17.0 \pm 1.0^{\mathrm{b}}$ & $14.6 \pm 0.5^{\mathrm{c}}$ & $7.6 \pm 0.5^{\mathrm{d}}$ & $27.0^{\mathrm{a}} \pm 0.0^{\mathrm{a}}$ \\
E.coli (ATCC 35150) & $16.3 \pm 1.5^{\mathrm{b}}$ & $13.6 \pm 1.5^{\mathrm{c}}$ & $10.0 \pm 1.0^{\mathrm{d}}$ & $28.3_{0.6^{\mathrm{a}}}$ \\
Cronobacter sakazakii & $15.0 \pm 1.0^{\mathrm{b}}$ & $12.0 \pm 1.7^{\mathrm{c}}$ & $9.3 \pm 0.5^{\mathrm{d}}$ & $25.6^{\mathrm{c}} \pm .6^{\mathrm{a}}$ \\
Aeromonas salmonicida & $16.6 \pm 0.5^{\mathrm{b}}$ & $9.3 \pm 0.5^{\mathrm{c}}$ & $8.0 \pm 1.0^{\mathrm{c}}$ & $27.0 \pm 1.0^{\mathrm{a}}$ \\
\hline
\end{tabular}

Mean values with a different letters (a, b, c, and d, respectively) were significantly different $(p<0.05$, ANOVA, DMRT) in the columns.

\subsection{In Vitro Antioxidant Assays}

The reducing power of the extracts increased in a concentration-dependent manner. In particular, the flower extracts had the highest antioxidant capacity among the different parts tested (Figure 2a). The DPPH free radical scavenging activity was determined using methanol extracts from the different parts of Korean mint at different concentrations (50 to $250 \mu \mathrm{g} / \mathrm{mL}$; Figure $2 \mathrm{~b}$ ). The flower extracts had the highest antioxidant capacity among the parts tested. Methanol extracts from the flowers, leaves, and stems had $80.9 \pm 1.1 \%, 39.2 \pm 1.2 \%$, and $16.3 \pm 0.7 \% \mathrm{DPPH}$ activities, respectively, at a concentration of $250 \mu \mathrm{L} / \mathrm{mL}$, whereas the ascorbic acid DPPH activity was $88.9 \pm 0.8 \%$. The hydrogen peroxide radical scavenging activity of the extracts from the different plant parts was also concentration-dependent (Figure 2c). This assay showed that an increase in the concentration of the extracts led to a rise in the radical scavenging activity. At $250 \mu \mathrm{L} / \mathrm{mL}$, the flower extract had the highest scavenging activity $(40.8 \pm 0.8 \%)$, whereas the radical scavenging activity of ascorbic acid was $76.8 \pm 0.6 \%$. Superoxide radical scavenging activity was determined using methanol extracts at different concentrations (50 to $250 \mu \mathrm{g} / \mathrm{mL}$; Figure 2d). At $250 \mu \mathrm{L} / \mathrm{mL}$, ascorbic acid had $80.6 \pm 0.3 \%$ scavenging activity, whereas the scavenging activities of the methanol extracts from the flowers, leaves, and stems were $38.8 \pm 1.1 \%, 23 \pm 1.4 \%$, and $20 \pm 0.6 \%$, respectively.

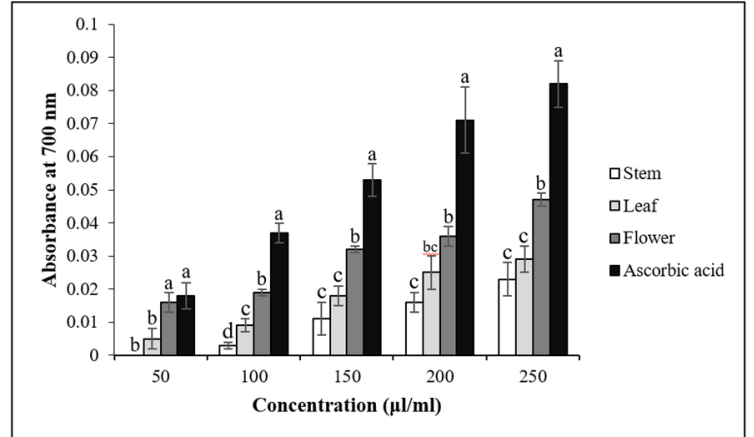

(a)

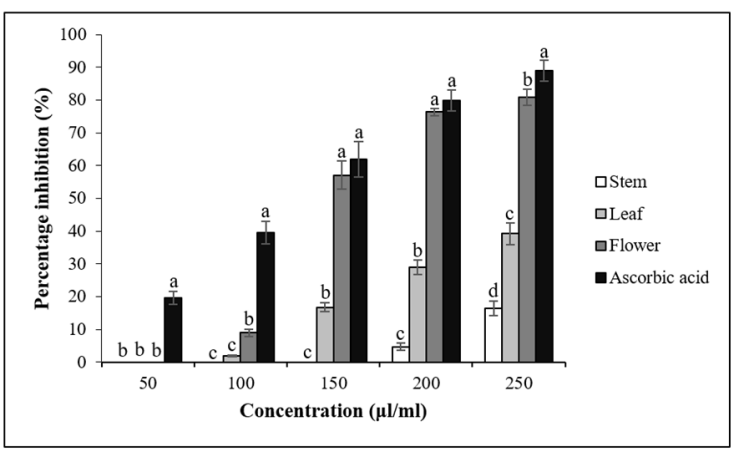

(b)

Figure 2. Cont. 


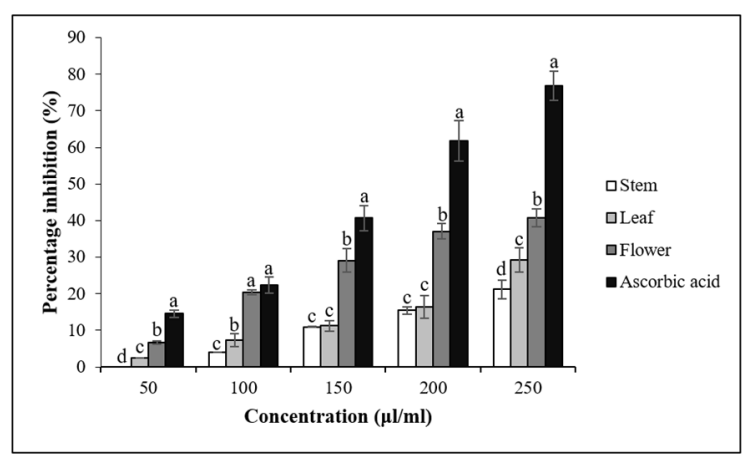

(c)

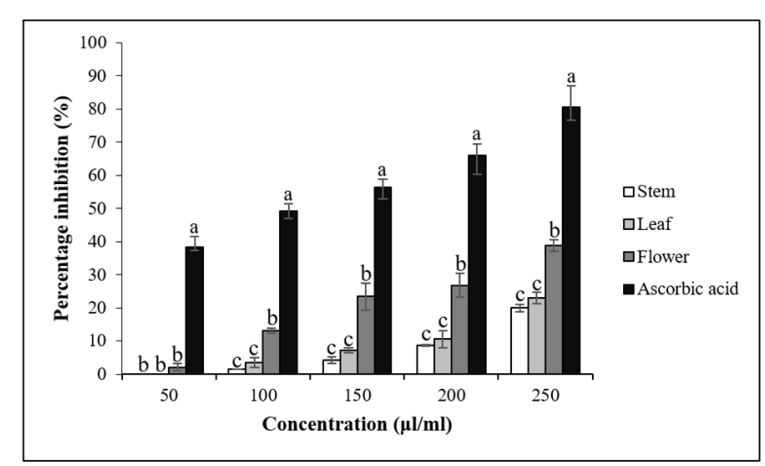

(d)

Figure 2. Antioxidant activity of the methanol extracts of stem, leaves, and flowers of $A$. rugosa. (a) Reducing power assay; (b) DPPH radical scavenging assay; (c) Hydrogen peroxide radical scavenging assay; (d) Superoxide radical scavenging assay. All of the values in the figure are expressed as means (\%) of triplicated experiments and standard deviation of three experiments. Mean values with a different letters ( $a, b, c$, and $d$, respectively) were significantly different ( $p<0.05$, ANOVA, DMRT).

\section{Discussion}

In this study, the methanol extracts from the different parts had wide-spectrum antibacterial activity. However, the flower extract had a greater efficacy than the leaf and stem extracts. The antioxidant activities of the methanol extracts from the different plant parts were measured as the ability of the extracts to scavenge hydroxyl radicals. The methanol extracts had concentration-dependent antioxidant properties. The flower extracts had the greatest potential antioxidant activity, which was possibly because they had higher phenylpropanoids levels. Korkina (2007) reported that phenylpropanoids, the largest group of plant secondary metabolites, are considered to be naturally occurring antioxidant and antibacterial agents [31].

Three flavonoids (kaempferol, catechin, and rutin) and three phenolic acids (ferulic acid, chlorogenic acid, and caffeic acid) were identified in the three different $A$. rugosa parts after the HPLC analysis. These findings were in agreement with previous studies, which had also reported the presence of ferulic acid in A. rugosa cells [32], chlorogenic acid and caffeic acid in A. rugosa [33,34], and quercetin and kaempferol in Agastache mexicana [35]. Phenolic compounds are natural antioxidants that can donate electrons to oxidative molecules [36,37]. Catechin, rutin, and kaempferol have been reported to possess effective antioxidant properties [38,39]. Anthocyanins, which belong to the flavonoid class, are also powerful natural antioxidants [40]. Hydroxybenzoic acid (4-hydroxybenzoic acid) and hydrocinnamic acids (chlorogenic acid, ferulic acid, and caffeic acid) are considered to be potential antioxidants [41,42]. Furthermore, the phenolics identified in this study have been reported to possess effective antibacterial properties [43-47].

The in vitro antioxidant and antibacterial activity assays showed that antibacterial and antioxidant activities were higher in the flowers than in the stems and leaves. These properties might be due to the higher phenolic levels in flowers. A previous study reported that flowers produced the most rosmarinic acid, tilianin, and acacetin, which possess antibacterial and antioxidant activities [11]. Furthermore, this study showed that flowers had the highest total flavonoid, anthocyanin, and phenolic contents, even when the leaves contained higher levels of ferulic acid, caffeic acid, and catechin. Therefore, the increased accumulation of phenylpropanoid compounds in flowers explains their greater antibacterial and antioxidant activities compared to stems and leaves. The findings are consistent with previous studies, which demonstrated that red cultivars of Lactuca sativa had higher concentrations of total anthocyanins, flavonoids, and phenolics, and thus showed higher antioxidant activities than green cultivars [48]. Furthermore, the red cultivar of Raphanus sativus contained higher levels of phenolic compounds and exhibited greater antioxidant effects than the white cultivar did [26]. 
All of the plant parts, including the wood, seed, bark, stem, pod, leaf, fruit, root, flower, and pollen, contain diverse natural antioxidants [49]. In particular, flowers are considered to be a potential source of bioactive phytochemicals with high antioxidant [50]. In this study, the flowers showed higher antioxidant ability than the stems and leaves. This finding was consistent with a previous study describing that the extract of the Ferulago angulate flower indicated better activity in DPPH radical scavenging than that of leaf and stem extract [51]. Bettaieb et al. (2010) also reported that the essential oil and acetone extract of Cuminum cyminum L. flowers were found to be the most effective in the DPPH, $\beta$-carotene/linoleic acid, and reducing power assays compared to those of the stem and leaves [52]. Furthermore, the flowers of Ixora coccinea possessed higher antioxidant ability than the stem and leaves [53].

The methanol extracts from the different parts of $A$. rugosa possessed antibacterial activities against all the bacterial strains tested. They also had antioxidant properties. However, the plant parts had significantly different antibacterial and antioxidant activities. These differences may be due to the different phytochemical constituents of the extracts. The secondary metabolites in the different parts of Korean mint have differing effects, including antioxidant and antibacterial activities [54,55] Agastache species have attracted great attention because these plants contain several phytochemicals and can be used as seasoning agents, flavoring agents, spices, herbs, and functional foods. They have also been exploited by the medical and cosmetic industries as antimicrobial and antioxidant agents.

Variations in the results obtained for the stems, leaves, and flowers of Korean mint or potential variations between the results reported by previous studies and those reported by this study are not surprising. This may be because ecological factors have led to variations in the chemical composition [56], and/or differences in the extraction solvents, seasons, and the phytochemicals that are present [57]. Furthermore, environmental factors, including drought or excessive rainfall, can affect the quantity and quality of bioactive compounds [58].

The World Health Organization (WHO) has reported that about $80 \%$ of the global population relies on herbal remedies for their primary healthcare $[59,60]$. This study showed that the different parts of $A$. rugosa have different antibacterial and antioxidant activities. These properties could be successfully used to treat several diseases caused by oxidative stress and bacterial infections. This may indicate that the medicinal plants exploited in traditional remedies may possess beneficial biological activities, including antioxidant or antimicrobial activities. Substantial research is being conducted by pharmaceutical and biomedical corporations into traditional remedies [61-63] and the toxicology of the phytomedical compounds in such preparations [64,65]. Therefore, this study supports the potential use of $A$. rugosa stems, leaves, and flowers in traditional herbal medicine applications.

\section{Conclusions}

Phenolic compounds were quantified in the leaves, flowers, and stems of $A$. rugosa by HPLC analysis, and the total anthocyanin, flavonoid, and phenolic contents were assessed. The methanol extracts of the different plant parts were found to have significant antibacterial and antioxidant activities. The flowers contained the highest total phenolic, flavonoid, and anthocyanin levels, which explains why they had greater antibacterial and antioxidant effects than the leaves and stems. This study shows that there are synergistic antimicrobial and antioxidant capabilities that are derived from phenylpropanoids in the stems, leaves, and flowers of A. rugosa.

Supplementary Materials: The following are available online at http:/ / www.mdpi.com/2076-3921/8/3/75/s1, Figure S1: LC-MS spectrum of phenolic compounds identified in leaves of A. rugosa. 1, Catechin; 2, Tilianin; 3, Ferulic acid; 4, Chlorogenic acid; 5, Caffeic acid; 6, Rutin; 7, trans-p-hydroxy cinnamic methyl ester; 8, Kaempferol., Table S1: List of detected phenolic compounds and their retention times $\left(t_{R}\right)$, and molecular $\left([\mathrm{M}-\mathrm{H}]^{-}\right)$and fragment ions in negative mode in A. rugosa leaf.

Author Contributions: S.Y.L. and S.U.P. designed and carried out the experimental part of the manuscript. C.H.P., H.J.Y., Y.E.P., T.B.B., and J.S.P. performed the experiments and wrote the paper. C.H.P., T.B.B., and H.J.Y. were involved in analyzing and monitoring the data and experiment. All of the authors read and approved the final manuscript. 
Funding: This work was supported by Korea Institute of Planning and Evaluation for Technology in Food, Agriculture, Forestry and Fisheries (IPET) through Advanced Production Technology Development Program, funded by Ministry of Agriculture, Food and Rural Affairs (MAFRA) (116068-03-2-SB010).

Conflicts of Interest: The authors declare no conflict of interest.

\section{References}

1. Jun, H.-J.; Chung, M.J.; Dawson, K.; Rodriguez, R.L.; Houng, S.-J.; Cho, S.-Y.; Jeun, J.; Kim, J.-Y.; Kim, K.H.; Park, K.W.; et al. Nutrigenomic analysis of hypolipidemic effects of Agastache rugosa essential oils in HepG2 cells and C57BL/ 6 mice. Food Sci. Biotechnol. 2010, 19, 219-227. [CrossRef]

2. Kim, J. Phytotoxic and antimicrobial activities and chemical analysis of leaf essential oil from Agastache rugosa. J. Plant Biol. 2008, 51, 276-283. [CrossRef]

3. Kim, M.H.; Chung, W.T.; Kim, Y.K.; Lee, J.H.; Lee, H.Y.; Hwang, B.; Park, Y.S.; Hwang, S.J.; Kim, J.H. The effect of the oil of Agastache rugosa O. Kuntze and three of its components on human cancer cell lines. J. Essent. Oil Res. 2001, 13, 214-218. [CrossRef]

4. Chae, Y.; Hyun-Choong, O.; Song, J. Variability of the volatile composition of Agastache rugosa in South Korea. Acta Hortic. 2005, 675, 59-64. [CrossRef]

5. Lee, S.Y.; Xu, H.; Kim, Y.K.; Park, S.U. Rosmarinic acid production in hairy root cultures of Agastache rugosa Kuntze. World J. Microbiol. Biotechnol. 2008, 24, 969-972. [CrossRef]

6. Li, H.Q.; Liu, Q.Z.; Liu, Z.L.; Du, S.S.; Deng, Z.W. Chemical composition and nematicidal activity of essential oil of Agastache rugosa against Meloidogyne incognita. Molecules 2013, 18, 4170-4180. [CrossRef] [PubMed]

7. Hong, J.-J.; Choi, J.-H.; Oh, S.-R.; Lee, H.-K.; Park, J.-H.; Lee, K.-Y.; Kim, J.-J.; Jeong, T.-S.; Oh, G.T. Inhibition of cytokine-induced vascular cell adhesion molecule-1 expression; possible mechanism for anti-atherogenic effect of Agastache rugosa. FEBS Lett. 2001, 495, 142-147. [CrossRef]

8. Song, J.-H.; Kim, M.-J.; Kwon, H.-D.; Park, I.-H. Antimicrobial activity and components of extracts from Agastache rugosa during growth period. J. Food Sci. Nutr. 2001, 6, 10-15.

9. Shin, S.; Kang, C.A. Antifungal activity of the essential oil of Agastache rugosa Kuntze and its synergism with ketoconazole. Lett. Appl. Microbiol. 2003, 36, 111-115. [CrossRef]

10. Min, B.S.; Hattori, M.; Lee, H.K.; Kim, Y.H. Inhibitory constituents against HIV-1 protease from Agastache rugosa. Arch. Pharm. Res. 1999, 22, 75-77. [CrossRef]

11. Tuan, P.A.; Park, W.T.; Xu, H.; Park, N.I.; Park, S.U. Accumulation of tilianin and rosmarinic acid and expression of phenylpropanoid biosynthetic genes in Agastache rugosa. J. Agric. Food Chem. 2012, 60, 5945-5951. [PubMed]

12. Oh, H.M.; Kang, Y.J.; Lee, Y.S.; Park, M.K.; Kim, S.H.; Kim, H.J.; Seo, H.G.; Lee, J.H.; Chang, K.C. Protein kinase G-dependent heme oxygenase-1 induction by Agastache rugosa leaf extract protects RAW264. 7 cells from hydrogen peroxide-induced injury. J. Ethnopharmacol. 2006, 103, 229-235. [CrossRef]

13. Wilson, L.A.; Senechal, N.P.; Widrlechner, M.P. Headspace analysis of the volatile oils of Agastache. J. Agric. Food Chem. 1992, 40, 1362-1366. [CrossRef]

14. Park, C.H.; Yeo, H.J.; Kim, N.S.; Eun, P.Y.; Kim, S.-J.; Arasu, M.V.; Al-Dhabi, N.A.; Park, S.-Y.; Kim, J.K.; Park, S.U. Metabolic profiling of pale green and purple kohlrabi (Brassica oleracea var. gongylodes). Appl. Biol. Chem. 2017, 60, 249-257. [CrossRef]

15. Higdon, J.V.; Delage, B.; Williams, D.E.; Dashwood, R.H. Cruciferous vegetables and human cancer risk: Epidemiologic evidence and mechanistic basis. Pharmacol. Res. 2007, 55, 224-236. [CrossRef] [PubMed]

16. Douglas, C.J. Phenylpropanoid metabolism and lignin biosynthesis: From weeds to trees. Trends Plant Sci. 1996, 1, 171-178. [CrossRef]

17. Jahangir, M.; Kim, H.K.; Choi, Y.H.; Verpoorte, R. Health-Affecting Compounds in Brassicaceae. Compr. Rev. Food Sci. Food Saf. 2009, 8, 31-43. [CrossRef]

18. Thomas, C. Oxygen Radicals and the Disease Process; CRC Press: Amsterdam, The Netherlands, 1998; pp. 1-282.

19. Matés, J.M.; Pérez-Gómez, C.; De Castro, I.N. Antioxidant enzymes and human diseases. Clin. Biochem. 1999, 32, 595-603. [CrossRef]

20. Lobo, V.; Patil, A.; Phatak, A.; Chandra, N. Free radicals, antioxidants and functional foods: Impact on human health. Pharmacogn Rev. 2010, 4, 118-126. [CrossRef]

21. Shetty, A.; Magadum, S.; Managanvi, K. Vegetables as sources of antioxidants. J. Food Nutr. Disord. 2013, 2, 1-5. [CrossRef] 
22. Hudson, B.J. Food Antioxidants; Elsevier Science Publishers: London, UK, 2012; pp. 1-317.

23. García-Andrade, M.; González-Laredo, R.; Rocha-Guzmán, N.; Gallegos-Infante, J.; Rosales-Castro, M.; Medina-Torres, L. Mesquite leaves (Prosopis laevigata), a natural resource with antioxidant capacity and cardioprotection potential. Ind. Crops Prod. 2013, 44, 336-342. [CrossRef]

24. Park, C.H.; Baskar, T.B.; Park, S.-Y.; Kim, S.-J.; Valan Arasu, M.; Al-Dhabi, N.A.; Kim, J.K.; Park, S.U. Metabolic profiling and antioxidant assay of metabolites from three radish cultivars (Raphanus sativus). Molecules 2016, 21, 157. [CrossRef]

25. Kim, D.-O.; Jeong, S.W.; Lee, C.Y. Antioxidant capacity of phenolic phytochemicals from various cultivars of plums. Food Chem. 2003, 81, 321-326. [CrossRef]

26. Sutharut, J.; Sudarat, J. Total anthocyanin content and antioxidant activity of germinated colored rice. Int. Food Res. J. 2012, 19, 215-221.

27. Park, C.H.; Yeo, H.J.; Park, Y.J.; Morgan, A.; Valan Arasu, M.; Al-Dhabi, N.A.; Park, S.U. Influence of indole-3-acetic acid and gibberellic acid on phenylpropanoid accumulation in common buckwheat (Fagopyrum esculentum Moench) sprouts. Molecules 2017, 22, 374. [CrossRef] [PubMed]

28. Rejiniemon, T.S.; Hussain, R.R.; Rajamani, B. In-vitro functional properties of Lactobacillus plantarum isolated from fermented ragi malt. South Indian J. Biol. 2015, 1, 15-23.

29. Sunil, C.; Irudayaraj, S.S.; Duraipandiyan, V.; Al-Dhabi, N.A.; Agastian, P.; Ignacimuthu, S. Antioxidant and free radical scavenging effects of $\beta$-amyrin isolated from S. cochinchinensis Moore. leaves. Ind. Crops Prod. 2014, 61, 510-516. [CrossRef]

30. Balachandran, C.; Duraipandiyan, V.; Emi, N.; Ignacimuthu, S. Antimicrobial and cytotoxic properties of Streptomyces sp. (ERINLG-51) isolated from Southern Western Ghats. South Indian J. Biol. 2015, 1, 7-14. [CrossRef]

31. Korkina, L. Phenylpropanoids as naturally occurring antioxidants: From plant defense to human health. Cell. Mol. Biol. 2007, 53, 15-25.

32. Kim, Y.B.; Kim, J.K.; Uddin, M.R.; Xu, H.; Park, W.T.; Tuan, P.A.; Li, X.; Chung, E.; Lee, J.-H.; Park, S.U. Metabolomics analysis and biosynthesis of rosmarinic acid in Agastache rugosa Kuntze treated with methyl jasmonate. PLoS ONE 2013, 8, e64199. [CrossRef] [PubMed]

33. Lee, J.-J.; Lee, J.-H.; Gu, M.J.; Han, J.-H.; Cho, W.-K.; Ma, J.Y. Agastache rugosa Kuntze extract, containing the active component rosmarinic acid, prevents atherosclerosis through up-regulation of the cyclin-dependent kinase inhibitors p21WAF1/CIP1 and p27KIP1. J. Funct. Foods 2017, 30, 30-38. [CrossRef]

34. Desta, K.T.; Kim, G.S.; Kim, Y.H.; Lee, W.S.; Lee, S.J.; Jin, J.S.; Abd El-Aty, A.; Shin, H.C.; Shim, J.H.; Shin, S.C. The polyphenolic profiles and antioxidant effects of Agastache rugosa Kuntze (Banga) flower, leaf, stem and root. Biomed. Chromatogr. 2016, 30, 225-231. [CrossRef] [PubMed]

35. Zielińska, S.; Matkowski, A. Phytochemistry and bioactivity of aromatic and medicinal plants from the genus Agastache (Lamiaceae). Phytochem. Rev. 2014, 13, 391-416. [CrossRef] [PubMed]

36. Rice-Evans, C. Flavonoid antioxidants. Curr. Med. Chem. 2001, 8, 797-807.

37. Rice-Evans, C.; Miller, N.; Paganga, G. Antioxidant properties of phenolic compounds. Trends Plant Sci. 1997, 2, 152-159. [CrossRef]

38. Morel, I.; Lescoat, G.; Cogrel, P.; Sergent, O.; Pasdeloup, N.; Brissot, P.; Cillard, P.; Cillard, J. Antioxidant and iron-chelating activities of the flavonoids catechin, quercetin and diosmetin on iron-loaded rat hepatocyte cultures. Biochem. Pharmacol. 1993, 45, 13-19. [CrossRef]

39. Torel, J.; Cillard, J.; Cillard, P. Antioxidant activity of flavonoids and reactivity with peroxy radical. Phytochemistry 1986, 25, 383-385. [CrossRef]

40. Kähkönen, M.P.; Heinonen, M. Antioxidant activity of anthocyanins and their aglycons. J. Agric. Food Chem. 2003, 51, 628-633. [CrossRef] [PubMed]

41. Kang, Y.-H.; Park, Y.-K.; Lee, G.-D. The nitrite scavenging and electron donating ability of phenolic compounds. Korean J. Food Sci. Technol. 1996, 28, 232-239.

42. Natella, F.; Nardini, M.; Di Felice, M.; Scaccini, C. Benzoic and cinnamic acid derivatives as antioxidants: Structure- activity relation. J. Agric. Food Chem. 1999, 47, 1453-1459. [CrossRef] [PubMed]

43. Cushnie, T.T.; Lamb, A.J. Antimicrobial activity of flavonoids. Int. J. Antimicrob. Agents 2005, 26, $343-356$. [CrossRef] [PubMed]

44. Chong, K.P.; Rossall, S.; Atong, M. In vitro antimicrobial activity and fungitoxicity of syringic acid, caffeic acid and 4-hydroxybenzoic acid against Ganoderma boninense. J. Agric. Sci. 2009, 1, 15-20. [CrossRef] 
45. Lou, Z.; Wang, H.; Zhu, S.; Ma, C.; Wang, Z. Antibacterial activity and mechanism of action of chlorogenic acid. J. Food Sci. 2011, 76, M398-M403. [CrossRef] [PubMed]

46. Borges, A.; Ferreira, C.; Saavedra, M.J.; Simoes, M. Antibacterial activity and mode of action of ferulic and gallic acids against pathogenic bacteria. Microb. Drug Resist. 2013, 19, 256-265. [CrossRef] [PubMed]

47. Herald, P.; Davidson, P. Antibacterial activity of selected hydroxycinnamic acids. J. Food Sci. 1983, 48, 1378-1379. [CrossRef]

48. Park, C.H.; Yeo, H.J.; Baskar, T.B.; Kim, J.K.; Park, S.U. Metabolic Profiling and Chemical-Based Antioxidant Assays of Green and Red Lettuce (Lactuca sativa). Nat. Prod. Commun. 2018, 13, 315-322. [CrossRef]

49. Pratt, D. Natural antioxidants from plant material. In Phenolic Compounds in Food and Their Effects on Health II; Huang, M.T., Ho, C.T., Lee, C.Y., Eds.; ACS Symposium Series; ACS Publications: New York, NY, USA, 1992; Volume 507, pp. 54-71.

50. Kaisoon, O.; Siriamornpun, S.; Weerapreeyakul, N.; Meeso, N. Phenolic compounds and antioxidant activities of edible flowers from Thailand. J. Funct. Foods 2011, 3, 88-99.

51. Azarbani, F.; Saki, Z.; Zareei, A.; Mohammadi, A. Phenolic contents, antibacterial and antioxidant activities of flower, leaf and stem extracts of ferulago angulata (schlecht) boiss. Int. J. Pharm. Pharm. Sci. 2014, 6, 123-125.

52. Bettaieb, I.; Bourgou, S.; Wannes, W.A.; Hamrouni, I.; Limam, F.; Marzouk, B. Essential oils, phenolics, and antioxidant activities of different parts of cumin (Cuminum cyminum L.). J. Agric. Food Chem. 2010, 58, 10410-10418. [CrossRef] [PubMed]

53. Torey, A.; Sasidharan, S.; Latha, L.Y.; Sudhakaran, S.; Ramanathan, S. Antioxidant activity and total phenolic content of methanol extracts of Ixora coccinea. Pharm. Biol. 2010, 48, 1119-1123. [CrossRef]

54. Noumedem, J.A.; Mihasan, M.; Lacmata, S.T.; Stefan, M.; Kuiate, J.R.; Kuete, V. Antibacterial activities of the methanol extracts of ten Cameroonian vegetables against Gram-negative multidrug-resistant bacteria. BMC Complement. Altern. Med. 2013, 13, 26. [CrossRef]

55. Mahalakshmi, N.; Dhanasekaran, S.; Ravi, C.; Lingathurai, S. In-vitro antimicrobial activities of Pongamia glabra and Phyllanthus niruri. South Indian J. Biol. 2016, 2, 236-244. [CrossRef]

56. Bhakuni, D.S.; Dhar, M.; Dhar, M.; Dhawan, B.; Mehrotra, B. Screening of Indian plants for biological activity: Part II. Indian J. Exp. Biol. 1969, 7, 250-262.

57. Thaker, A.; Anjaria, J. Antimicrobial and infected wound healing response of some traditional drugs. Indian J. Pharmacol. 1986, 18, 171-174.

58. Vlachos, V.; Critchley, A.; Von Holy, A. Antimicrobial activity of extracts from selected Southern African marine macroalgae. S. Afr. J. Sci. 1997, 93, 328-332.

59. Akerele, O. Nature's medicinal bounty: Don't throw it away. World Health Forum 1993, 14, 390-395. [PubMed]

60. Ekor, M. The growing use of herbal medicines: Issues relating to adverse reactions and challenges in monitoring safety. Front. Pharmacol. 2014, 4, 177. [CrossRef]

61. Assob, J.C.; Kamga, H.L.; Nsagha, D.S.; Njunda, A.L.; Nde, P.F.; Asongalem, E.A.; Njouendou, A.J.; Sandjon, B.; Penlap, V.B. Antimicrobial and toxicological activities of five medicinal plant species from Cameroon Traditional Medicine. BMC Complement. Altern. Med. 2011, 11, 70. [CrossRef]

62. Yuan, X.; Chapman, R.L.; Wu, Z. Analytical methods for heavy metals in herbal medicines. Phytochem. Anal. 2011, 22, 189-198. [CrossRef] [PubMed]

63. Abdullah Al-Dhabi, N.; Valan Arasu, M.; Rejiniemon, T.S. In vitro antibacterial, antifungal, antibiofilm, antioxidant, and anticancer properties of isosteviol isolated from endangered medicinal plant Pittosporum tetraspermum. Evid. Based Complement. Altern. Med. 2015, 2015, 164261. [CrossRef]

64. Maruo, V.; Bernardi, M.; Spinosa, H. Toxicological evaluations of long-term consumption of Solanum lycocarpum St. Hill fruits in male and female adult rats. Phytomedicine 2003, 10, 48-52. [CrossRef] [PubMed]

65. Wintola, O.; Sunmonu, T.; Afolayan, A. Toxicological evaluation of aqueous extract of Aloe ferox Mill. in loperamide-induced constipated rats. Hum. Exp. Toxicol. 2011, 30, 425-431. [CrossRef] [PubMed]

(C) 2019 by the authors. Licensee MDPI, Basel, Switzerland. This article is an open access article distributed under the terms and conditions of the Creative Commons Attribution (CC BY) license (http:/ / creativecommons.org/licenses/by/4.0/). 